\title{
Banks' risk and the impact of audit quality on income smoothing
}

\author{
Konstantinos Vasilakopoulos ${ }^{1, \mathrm{a}}$, Christos Tzovas $^{\mathrm{a}}$ and Apostolos \\ Ballas $^{\mathrm{a}}$
}

${ }^{a}$ Athens University of Business and Economics, Greece

\begin{abstract}
Research question: This paper investigates the impact that specific audit quality dimensions have upon European Union Banks' income smoothing behavior.

Motivation: Although previous studies have investigated the characteristics of audit quality, little is known about the audit quality in the banking sector. Excessive risk taking and business complexity may further impair auditors' work and an audit's outcome may be conditioned upon banks' risk.
\end{abstract}

Idea: We examine whether auditors' independence influences bank managers' decision to smooth income and whether this attribute depends on bank risk and systemic importance. We investigate the association between auditors' industry specialization and auditors' tenure with the level of Loan Loss Provisions

Data: We use a sample of 133 banks from 26 European Union countries for the period 20062013.

Tools: Similar to previous research, we use ordinary least squares analysis to test the results. Findings: Empirical findings provide evidence that the auditors' industry expertise limits management's discretion of high-risk banks to a greater extent relative to low risk banks. In contrast, our results imply that banks that retain the same auditor for a consecutive fiscal year are more likely to engage in income smoothing through LLPs. Furthermore, our study examines whether audit quality dimensions have different outcomes on income smoothing decisions between globally systemically important banks (GSIBs) and the rest of banks. Our results provide evidence that the impact of industry specialization and auditor tenure on EU banks accounting policy decisions differs between GSIBs and non-GSIBs.

${ }^{1}$ Corresponding author: Konstantinos Vasilakopoulos, Department of Accounting and Finance, Athens University of Economics and Business, email address: kvasilakopoulos@gmail.com

Acknowledgment: This research has been supported by the "Accounting and Information Systems Laboratory", and the "Business Analysis and Valuation Laboratory", Dept. of Accounting and Finance, Athens University of Economics and Business 
Contribution: Our analysis contributes in the existing body of research by focusing on the impact of audit quality on managements' accounting discretion and the influence of banks' special attributes on the audit process.

Keywords: banks, provisions, income smoothing, auditor expertise, auditor tenure

\section{JEL Codes: G21, G14, M41, M42}

\section{Introduction}

In the face of the financial crisis of 2008, European Union (hereinafter EU) adopted a series of corrective measures aiming to ensure financial stability. Audit framework concentrated the interest of policy-makers due to the critical role of auditors in the provision of verification regarding firms' accounting quality. In October 2010, the European Commission issued a Green Paper that addressed critical issues which could impair the quality of audits. In line with the European Commission, several banking regulators such as the Basel Committee on Banking Supervision (hereinafter, BCBS) and the Financial Stability Board (hereinafter, FSB) suggested that auditors should provide assurance services regarding banks' risk data. As a result, risks of misstatement and costs of failure would be reduced.

To provide high quality assurance services, the auditors of banks should maintain high standards of independence and competence. Banks' audit function may differ from the audit of non-financial firms due to the special attributes of the banking sector. Banks' complex operations combined with the limited incentives of both supervisors and depositors to exert efficient monitoring, may encourage managers to engage in excessive risk-taking activities (Levine, 2003). Furthermore, managers who invest in risky assets may use aggressive accounting policies to conceal their opportunistic incentives and avoid a potential regulatory intervention (Leventis et al., 2011). In addition, governments' 'too-big-to-fail' policies may also deter effective monitoring by market participants and auditors (Barth et al., 2004).

According to the results of a survey conducted in 2013 by the International Forum of Independent Audit Regulators, bank audits by the world's six largest accounting firms have been found to be "persistently riddled with flaws" (Tepalagul \& Lin, 2015). The American Institute of Certified Public Accountants (hereinafter, AICPA) found that banks' loan loss allowance ranks number one among the various deficiencies found by inspectors (AICPA, 2006). The complexity of the financial system and the opaqueness of banks' assets suggest that a new approach to banks' audit may be required. Auditors should not restrict their role in providing assurance services but they should expand audit's scope by verifying the financial information 
within the framework of a risk-based approach that focuses on the IFRS principle "Substance over form" (European Commission Green Paper, 2010).

Although regulators and standard setters have outlined that banks' audits often had deficiencies related to loan loss provisions, only a few studies have examined the impact that auditor independence and audit quality have upon the financial statements prepared by financial institutions (Gaver \& Paterson, 2007; Kanagaretnam et al., 2010a).

This study uses income smoothing as an indication of accounting quality and investigates whether specific auditing characteristics, such as auditor industry specialization and auditor tenure, have an impact upon the EU banks managers accounting discretion, by focusing in income smoothing behavior. Auditors who are industry experts may perform better in error detection and financial fraud mitigation (Johnson et al., 1991; Carcello \& Nagy, 2004). Similarly, long auditor tenure may improve audit quality by increasing auditors' understanding about their clients' business and develop their expertise during the audit (Tepalagul \& Lin, 2015). However, banks' inherent risk and their systemic importance may influence auditors' judgments, resulting in adverse outcomes (Allen et al., 2006).

This study examines whether the impact of auditor specialization and tenure on smoothing behavior differs depending on each bank's idiosyncratic risk. In addition, our study aims to provide further insights in the research on the financial reporting of Globally Systemically Important Banks (hereinafter, GSIBs) and other banks.

We use a sample of 133 banks from 26 European Union countries (1064 observations) for the period 2006-2013. In line with previous research, we examine loan loss provisions (hereinafter, LLPs) as a smoothing accounting tool. To test our hypotheses, we conducted a univariate analysis and we run a multivariate regression model. Similarly, to previous research on income smoothing we use an OLS analysis to test our results.

Our results suggest that bank's inherent risk may alter the impact of certain audit quality dimensions on managers' income smoothing behavior. In particular, our study provides evidence that auditor industry expertise limits high risk banks' income smoothing through LLPs to a greater extent relative to low risk banks. In addition, auditors' retention limits managerial opportunism; however, this impact is greater for low risk banks relative to high risk banks. Regarding banks' systemic importance, our analysis provides evidence that auditor expertise and auditor tenure appear to have different outcomes between GSIBs and the rest of banks. In particular, when GSIBs have employed an industry expert or retained the same auditor appear to smooth income less than the rest of banks.

The findings of this study contribute to the existing literature concerning firms' income smoothing behavior with special reference to banks. In addition, our study 
contributes in the existing audit research by focusing on the impact of certain banks' attributes on specific audit quality dimensions. Our findings complement the findings of previous research that investigates the interaction of regulators and auditors upon loan loss provision timeliness and the income smoothing behavior of GSIBs vs. non-GSIBs (Nicoletti, 2018; Peterson \& Arun, 2018, Ugwu et al., 2020). Furthermore, our findings can be useful to practitioners and regulators who aim to enhance auditor independence and protect banks' stakeholders from managerial opportunism and fraud. This dimension can be of particular importance in the face of the debate that has been initiated regarding the new role of auditing in the smooth functioning of financial system.

\section{Literature review}

Literature suggests that banks' managers have strong incentives to engage in income smoothing and/or earnings management through accounting accruals, mainly LLPs. Banks' management incentives may be opportunistic aiming to expropriate wealth at the expense of stakeholders' purposes (Leventis et al., 2011; Ozili, 2017a, b; Olczak, 2015; Ozili, 2019). In addition, official supervision and the imposed minimum capital requirements may prompt banks to smooth income to avoid any potential regulatory intervention (Anandarajan et al., 2007; Curcio \& Hasan, 2015). In addition, the efficiency of corporate governance mechanisms may also determine the incentives of bank managers to engage in discretionary accounting choices (Vasilakopoulos et al., 2018). On the other hand, managers may use income smoothing to signal their private information to outside stakeholders (Beaver \& Engel, 1996; Kanagaretnam et al., 2005, Tran et al., 2019).

Banks' complex operations and the moral hazard problem, which derives from the existence of deposit insurance, may encourage managers to engage in excessive risktaking activities (Levine, 2003). Within this context, Fang et al. (2014) argue that stricter legal enforcement and solid accounting standards reduce managerial engagement in discretionary activities and require high accounting compliance that deters earnings management.

In order to improve transparency and accounting quality the EU adopted the IFRS accounting framework from the $1^{\text {st }}$ January 2005 . Moreover, the EU perceived the risks that derive from financial innovation and the complexity of banks' operations and adopted the new regulatory framework of the Basel Accord II, which came into effect on 2008 and replaced the Basel Accord I. A series of studies investigated the impact of the IFRS adoption upon banks' accounting discretion and provided evidence that the new accounting framework limited but did not eliminate management's income smoothing incentives (Gebhardt \& Farkas, 2011; Hamadi et al., 2016;). 
The financial crisis of 2008 raised questions about banks' governance mechanisms and accounting quality. In fact, numerous banks were given clean audit reports during the crisis period despite they had recognized huge losses from on and offbalance sheet figures. Therefore, several stakeholders claimed that the existent legislative framework was inadequate for protecting them (Commission Communication of 4 March 2009) and that the EU should re-examined the audit framework. Subsequently, in October 2010, the European Commission issued a Green Paper in order to address potential problems that were related with audit policies and the role of auditors. In particular, the Green Paper suggested that auditors should abandon the concept of "reasonable assurance" about the informational content of a firm's financial statements and adopt adopting a "substance over form" approach, which includes ensuring that there is no arbitrage of the differences in regulatory frameworks between jurisdictions.

Auditors are valuable for the financial system because their work alleviates the potential conflicts between managers, owners and other stakeholders (Watts \& Zimmerman, 1981; Tessema, 2020). In fact, an audit opinion comprises an independent verification that management has prepared a firm's financial statements according with the related accounting framework. Within this context, DeAngelo (1981) argued that auditors' opinion is associated with an audit's quality dimension, which in turn, depends on the joint probability that an auditor will discover a breach in the clients' accounting system and he/she will report this breach.

Previous studies examined a series of factors that impair audit quality and are related either with auditors' independence (Krishnan \& Krishnan, 1996; Li, 2009) or with auditors' competence (Shaub and Lawrence, 1996). However, related evidence comes from the non-financial sector and only a few studies have examined the impact of audit quality on financial firms (Gaver \& Paterson, 2007; Kanagaretnam et al., 2010a; Salem et al.,2021).

Banking sector's information uncertainty may increase due to the greater complexity of banking operations and difficulty of assessing risk on the large portfolio of loans (Autore et al., 2009). Within this context, if high risk banks use accounting accruals to mask excessive risk taking and management' s opportunistic incentives, the stage of risk assessment may be severely impaired and consequently the overall audit quality may decline.

Literature posits that there is an inverse relationship between the level of bank capital and risk exposure (Shrieves \& Dahl, 2003; Yasuda et al., 2004). Within this context, riskier banks are more likely to engage in earnings and capital management (Leventis et al., 2011). In particular, capital is used to absorb unexpected losses arising from credit risk, interest rate risk and liquidity risk. As a result, it comprises a critical figure that generates confidence to stakeholders regarding a bank's financial 
strength. Therefore, bank managers may mask their bank's excessive risk by adjusting capital and earnings through discretionary accounting policies.

Given that the riskiness of an auditor's client is dependent on the complexity of transactions and accounting systems in place, audit process can be influenced by management's incentives to prepare reliable financial statements. Empirical findings provide evidence that the degree of client complexity and risk significantly influence audit procedures in terms of the planned extent or hours of testing (Caramanis \& Lennox, 2011; Cardelon et al., 2012), the nature of planned testing (Hackenbrack \& Knechel, 1997) and the personnel assigned to the audit (Johnstone \& Bedard, 2001).

A client' risk assessment comprises the first stage of the audit process and may influence the overall quality of the audit. Risk assessment appears to be the most important stage because it determines the nature and the extent of the planned procedures (Allen et al., 2006). Besides, the modification of the planned procedures may become difficult if an auditor's initial risk perception is false (Hammersley et al., 2011). Furthermore, auditors' selected approach to assess a client's risk may lead to adverse outcomes (Wilks \& Zimbelman, 2004).

Although audit process may be influenced by a bank's idiosyncratic risk, management discretionary accounting accruals may comprise another throwback, as well. AICPA found that banks' loan loss allowance ranks number one among the various deficiencies found in banks' financial statements (AICPA, 2006). This implies that auditing banks' income smoothing practices through LLPs comprises a challenging task. If auditors fail to discover a potential breach, while assessing the adequacy of loan losses, may suffer from a loss of their reputation (Kanagaretnam et al., 2010b). Given, that the vast majority of EU banks is audited by Big-5 auditors, industry expertise may comprise the most important audit characteristic with regard to the audit quality of the banking industry. Although a Big 5 auditor may serve clients in multiple industries, the auditors may not have a competitive advantage in all industries. Dominating an industry seems very costly due to limited human capital with industry expertise and constrained economic resources (Kanagaretnam et al., 2009).

Kanagaretnam et al. (2010b) examined industry expertise in the banking sector and found that industry specialization mitigates banks' benchmark-beating incentives through discretionary accruals. This quality dimension plays a more important role in mitigating earnings management than the classification of auditors as a Big-5. These findings are in line results for non-financial firms which documented that industry specialization lowers discretionary accruals and mitigates financial fraud (Carcello \& Nagy, 2004; Krishnan, 2003). However, in the case of banks, risk plays an important role for managers' accounting discretion. Leventis et al. (2011) found that riskier banks are more likely to engage more in earnings management strategies, 
even after the implementation of IFRS. Within this context, although industry specialization has a negative association with earnings management through LLPs, inherent bank risk may differentiate the influence of this quality dimension on banks' income smoothing behavior. Therefore, we formulate the following hypothesis:

H1: The impact of industry specialization on the association between loan loss provisions and earnings before provisions and taxes for high risk banks is not significantly different than the impact of industry specialization on the association between loan loss provisions and earnings before provisions and taxes for low risk banks.

Auditor tenure comprises another important dimension of audit quality and as result has an impact on financial reporting quality (Lin \& Hwang, 2010). In the Green Paper of 2010, the European Commission states that "Situations where a company has appointed the same audit firm for decades seem incompatible with desirable standards of independence". However, literature's interpretation about the impact of auditors' tenure on audit quality seems controversial. A series of studies suggest that as the auditor-client relationship lengthens, auditors become more likely to act in favor of management, a fact that reduces audit quality (Carey \& Simnett, 2006; Bamber \& Iyer, 2007). The opposing view suggests that short tenure means an auditor has less knowledge of a client, which results to greater opportunities for fraud and earnings management. Within this context, Johnson et al. (2002) argue that long tenure enhances auditor expertise.

Previous findings regarding the impact of tenure on accounting quality are mixed. A series of studies have reported a positive relation between auditor tenure and earnings quality (Myers et al., 2003; Chen et al., 2008), while Carey and Simnett (2006) find no association between the two variables in the case of Australian firms. In addition, Davis et al. (2009) found that auditor tenure is associated with higher earnings management in both short and long tenure situations, but this is only observable prior to the passage of the Sarbanes-Oxley Act.

In the case of banks, auditors' tenure may be conditioned upon a bank's idiosyncratic risk as well. High risk banks, which are encouraged to use discretionary accounting policies and conceal their excessive risk, may seek for a short term audit- client relationship. Thus, they will deter auditors to understand their business and detect material misstatements (Knapp, 1991). In contrast, low risk banks will have fewer incentives for a quick audit rotation. Furthermore, high risk banks may be a potential threat for an audit firm's reputation. Within this context, auditors of riskier banks may abandon their client and sacrifice future economic benefits for the retention of their reputation (Beeler \& Hunton, 2002; Chang \& Hwang, 2003). As a result, banks who aim to have a long-term relationship with their auditors may have fewer 
incentives to smooth income through LLPs, relative to banks who seek a quick audit rotation. Therefore, we formulate the following hypothesis:

H2: The impact of auditor's tenure on the association between loan loss provisions and earnings before provisions and taxes for high risk banks is not significantly different than the impact of auditor's tenure on the association between loan loss provisions and earnings before provisions and taxes for low risk banks.

The size of a client may influence independence as well. An auditor is more likely to yield to pressures from larger clients, and as a consequence to compromise his independence (Hribar et al., 2010). Within this context, auditors are less likely to issue modified, qualified or going concern opinions for their large clients (Blay \& Geiger, 2013). In addition, Sharma et al. (2011) found that although there is a positive association between clients' importance and earnings management, an effective audit committee may mitigate such conflicts.

The problem of large clients may be even greater in the banking industry where the "too big to fail policy" and the notion of globally systemically important banks exist. The "too big to fail" theory asserts that certain corporations, particularly banks, are so large and so interconnected with other financial institutions that a possible failure would be disastrous to the greater economic system. This seems to be particularly the case for global systemically important banks (GSIBs), which are complex organizations with hundreds of subsidiaries that operate globally under different regulations and legal requirements.

Although the studies of Gaver and Paterson (2007) and Kanageretnam et al. (2010b) showed that that auditors tolerate less earnings management in larger clients of the financial sector, the financial and political strength of GSIBs may influence auditors' judgments. Yet, Petersen and Arun (2018) argued that GSIBs are large firms and consequently tend to smooth income or manage earnings to a greater extent compared to smaller firms. In particular, they found that GSIBs engaged more in income smoothing through LLPs relative to non GSIBs when they have substantial non-performing loans and they aim to meet/exceed minimum regulatory capital ratios. Therefore, governments' favorable policies may prompt GSIBs to conceal managers' opportunistic behavior by adjusting accounting accruals such LLPs. On the other hand, non GSIBs may be more constrained with regard to their accounting policy decisions, because their monitors may tolerate fewer deviations from regulatory standards. Within this context, the impact of auditor industry expertise and audit tenure on audit quality may not be the same for GSIBs and non-GSIBs. Therefore, we formulate the following hypotheses:

H3: The impact of auditor expertise on the association between loan loss provisions and earnings before provisions and taxes for G-SIBs is not significantly different 
than the impact of auditor expertise on the association between loan loss provisions and earnings before provisions and taxes for non G-SIBs.

H4: The impact of auditor tenure on the association between loan loss provisions and earnings before provisions and taxes for G-SIBs is not significantly different than the impact of auditor tenure on the association between loan loss provisions and earnings before provisions and taxes for non G-SIBs.

\section{Research design}

Our sample consists of 1,064 annual observations drawn from 26 countries and covering 2006 to 2013. The sample comprises of 133 banks. Gebhardt and Farkas (2011) examined data for 90 banks in 15 EU countries. Similarly, Hamadi et al. (2016) examined 103 banks from 24 EU countries. Banks domiciled in Luxembourg are not included in our sample due to missing data. We use 2006 as the base year for our analysis because the EU adopted IFRS on January 1, 2005. Many of the 2005 financial statements were prepared under IFRS 1, which allowed a number of exceptions for first-time adopters. Using 2005 as the base year would have included in our sample firms that did not operate in a completely uniform accounting environment. Our analysis ends in 2013 because new reforms in the banking sector came into effect after that year. The establishment of the Single Supervisory Mechanism (SSM) made official supervisions in the Euro-area different from that elsewhere. Furthermore, the preparations for Basel Accord III adoption, the directive for the resolution of banking crises (BRRD), and the actions taken for Shadow Banking may have influenced both managers' and monitors' incentives.

Banks and other public interest entities domiciled in the EU were required to prepare their financial statements in accordance with IFRS from January 1, 2005. Furthermore, the EU has adopted both Basel Accords (I \& II). Subsequently, all banks in our sample report their financial statements under a uniform accounting framework (IFRS) and operate under a uniform regulatory environment.

As in Gebhardt and Farkas (2011) and Hamadi et al. (2016), our data were hand collected from the annual reports of EU banks published on their websites. This hand collection was driven by a large number of missing observations regarding LLPs, non-performing loans, and net charge-offs. Table 1 describes our sample construction. Our initial database consisted of 8019 active financial institutions according to the records of the European Central Bank in 2014. We exclude all the financial institutions that were not assessed by a rating agency in order to include only the banks that attract the interest of independent market participants. In our initial sample, 2021 financial institutions were rated by at least one agency. Furthermore, in line with Anandarajan et al. (2007), each selected bank had to 
provide data for all of our variables during the study period in its annual report. Thus, we exclude every bank with at least one missing observation, creating a sample of 133 banks from 26 EU countries.

The following table (Table 1) summarizes the way we ended up in our final sample:

Table 1. Sample selection

\begin{tabular}{lc}
\hline Total number of credit institutions in the ECB record of 2014 & 8019 \\
Minus: Credit institutions without assessment from a rating agency & 5998 \\
Banks that attract the interest of market independent participants & $\mathbf{2 0 2 1}$ \\
$\begin{array}{l}\text { Minus: Total numbers of banks without full range of accounting data for } \\
\text { the period of 2006-2013 }\end{array}$ & 1898 \\
Minus: Number of outliers & - \\
Total numbers of banks in the final sample & $\mathbf{1 3 3}$ \\
\hline
\end{tabular}

In order to test our hypotheses, we run a multivariate model. Our model consists of a series of variables that capture income smoothing through LLPs and are analyzed by Beatty and Liao (2014). Furthermore, our model includes specific independent variable variables depict banks' risk and audit quality. In order investigate separately the impact of auditors' industry expertise and audit tenure we use the following equations:

$\mathrm{LLPt}=\beta 0+\beta 1 \mathrm{X} \mathrm{NPLt}+\beta 2 \mathrm{X} \Delta \mathrm{NPLt}+\beta 3 \mathrm{X} \mathrm{COt}+\beta 4 \mathrm{X} \mathrm{ALW} \mathrm{t}-1+\beta 5 \mathrm{X} \mathrm{SIZEt}-$ $1+\beta 6 \mathrm{X} \Delta \mathrm{GDPt}+\beta 7 \mathrm{X} \Delta \mathrm{UNEMPt}+\beta 8 \mathrm{X} \Delta \mathrm{LOANt}+\beta 9 X \mathrm{LOANt}+\beta 10 X E B P T t$ $+\beta 11 X$ RISK + $\beta 12$ X AUDEXP + $\beta 13$ X (EBPTt X RISK X AUDEXP $)+$ $\Sigma$ Countryfixed effects $+\Sigma$ Period fixed effects + et (MODEL1)

$\mathrm{LLPt}=\beta 0+\beta 1 \mathrm{X} \mathrm{NPLt}+\beta 2 \mathrm{X} \Delta \mathrm{NPLt}+\beta 3 \mathrm{X} \mathrm{COt}+\beta 4 \mathrm{X} \mathrm{ALW} \mathrm{t}-1+\beta 5 \mathrm{X} \mathrm{SIZEt}-$ $1+\beta 6 \mathrm{X} \Delta \mathrm{GDPt}+\beta 7 \mathrm{X} \Delta \mathrm{UNEMPt}+\beta 8 \mathrm{X} \Delta \mathrm{LOANt}+\beta 9 X L O A N t+\beta 10 X E B P T t$ $+\beta 11$ X RISK $+\beta 12$ X AUDRENURE + $\beta 13$ X $($ EBPTt X RISK X AUDTENURE $)+$ $\Sigma$ Country fixed effects + EPeriod fixed effects + et (MODEL2)

Where:

LLPt Loan loss provisions at the end of year $t$ scaled by lagged total loans

NPLt Change in non-performing assets at the end of the current year $t$ divided by lagged total loans

$\triangle \mathrm{NPLt} \quad$ Change in non-performing assets at the end of the current year $t$ divided by lagged total loans 
$\mathrm{COt}$

ALWt-1

SIZEt-1

$\Delta \mathrm{GDPt}$

$\triangle \mathrm{UNEMPt}$

$\triangle \mathrm{LOANt}$

LOANt

EBPTt

RISK

AUDEXP

AUDTENURE

EBPTt X RISK

$\mathrm{X}$ AUDEXP

\section{EBPTt X RISK X AUDTENURE}

Net Charge -offs of the current year $t$ scaled by lagged total loans

Loan loss allowance at the end of the previous year $\mathrm{t}-1$ divided by total loans

The natural log of total assets of the previous year t-1

Change in GDP at the end of the current year $\mathrm{t}$

Change in unemployment rates at the end of the current year $t$

Change in total loans at the end of current year $t$ divided by lagged total loans

Total loans at the end of the current year $t$ divided by total assets

Earnings before taxes and provisions at the end of the current year $t$ scaled by lagged total loans

Dummy variable that takes the value 1 if a banks is classified as high risk and 0 otherwise

Dummy variable that takes the value 1 if auditor is classified as expert and 0 otherwise A dummy variable, 1 if the audit firm is switched at time $t$, and 0 otherwise

Interaction term between earnings before taxes and provisions (EBPTt) RISK and auditors' expertise (AUDEXP)

Interaction term between earnings before taxes and provisions (EBPTt) RISK and auditors tenure (AUDTENURE)

Our multivariate model is developed in two parts. The first part aims to capture factors that influence LLPs' non- discretionary components (Hamadi et al., 2016). In particular, banks will recognize an amount of LLPs that will reflect the credit risk of their assets, regardless management's incentives for opportunistic income smoothing or signaling private information. The second part of our model consists of variables that aim to capture the relation of LLPs with income smoothing and its interaction with risk and audit quality.

Our independent variable is the reported LLPs (LLPt) at the end of the each period. The accounting treatment of LLPs is based on IAS 39, which requires the recognition of an expense amount that reflects managements' expectations about future loan losses that will occur due to current overdue loans. These provisions will be reversed during next year, when actual loan losses will occur. According to the relative 
guidelines, the recognition of a provision expense should be based on the objective evidence of the loss and any forward-looking provisions are prohibited. However, the lack of specific guidelines about the circumstances that comprise objective evidence about future loan losses encourages managers to use LLPs as a smoothing device.

Banks recognize loan loss provisions in order to reflect their expectations about the losses that will occur due to the credit risk that exists throughout their loan portfolio. Banks could compute potential loan losses assessing either each and every large loan or groups of smaller and homogeneous loans. Within this context, the amount of nonperforming loans (NPLt) and the amount of non-performing loans (NPLt) could comprise a reliable indication about the credit risk of each bank of our sample (Hamadi et al., 2016). As a result, both non-performing loans of the current year (NPLt) and their change during the current year $(\triangle \mathrm{NPLt})$ are expected to be positively associated with loan loss provisions. Furthermore, according to the accounting rules, current year's LLPs are expected to be reversed within next year, when actual loan losses will occur. Thus, we follow Nichols et al. (2009), including current year' charge-offs (COt) in the regression model, which are predicted to have a negative association with current year's LLPs.

Past LLPs accounting policies may have an impact on current year's LLPs. The rationale for controlling for past allowance is that if banks recognize sufficiently high provision in the past, the current year's LLPs may be lower. However, if past allowance reflects the overall credit quality of the bank's clients, then lagged allowance and provision may be positively correlated (Beatty and Liao, 2014). Within this context, we control for the impact of loan loss allowance of the previous year (ALWt-1) on current years' LLPs and we expect a positive correlation between LLPs and loan loss allowance of the previous year (ALWt-1).

Prior literature suggests that larger firms tend to smooth income or manage earnings to a greater extent compared to smaller firms. In particular, managers of larger firms will prefer to use accounting procedures that decrease high earnings for fear of political and/or regulatory scrutiny of bank earnings (Zimmerman, 1983). Therefore, we use size (SIZEt-1) to control for different levels of accounting discretion regarding each banks' regulatory scrutiny or monitoring mechanisms.

Many studies suggest that the amount of LLPs is influenced by macroeconomic factors. We follow Laeven and Majnoni (2003) and Bikker and Metzemakers (2005) and we control for a country's macroeconomic condition by including the annual growth of GDP ( $\triangle \mathrm{GDPt})$, the annual growth of a bank' loans ( $\triangle$ LOANt), the annual unemployment rates ( $\triangle \mathrm{UNEMPt}$ ) and total banks' lending amounts (LOANt). Beatty and Liao (2011) argue that LLPs may be higher when a bank extends credit to more clients with lower credit and vice versa. Within this context, we predict a positive association between our dependent variable and loan growth ( $\triangle \mathrm{LOANt})$ and total lending (LOANt). Furthermore, the growth of GDP ( $\Delta \mathrm{GDPt})$ and the unemployment 
rate $(\triangle \mathrm{UNEMPt})$ reflect the overall economic condition of a country. During economic booms GDP growth is expected to be positive and unemployment rates low. Thus, banks' clients credit quality is expected to be higher during booms and subsequently banks are expected to recognize lower LLPs during such period. In contrast, banks will recognize higher LLPs in recession periods due to expected deterioration of their clients' creditworthiness. Therefore, we expect a negative association between LLPs with GDP growth $(\triangle \mathrm{GDPt})$ and a positive relation with unemployment rates $(\triangle \mathrm{UNEMPt})$.

The income smoothing hypothesis suggests that managers deliberately increase LLPs when earnings are high in order to create an inventory of income for a 'rainy day' (Greenawalt \& Sinkey, 1998). When earnings are low, managers can either deliberately understate LLPs or reverse the previous year's recognized provisions to offset unexpected losses (Laeven \& Majnoni, 2003). Within this context, we capture managers' income smoothing behavior by including earnings before provisions and taxes (EBPTt). If managers aim to smooth income, LLPs will be positively associated with earnings before provisions and taxes (EBPTt).

The underlying assumption of hypotheses $\mathrm{H} 1$ and $\mathrm{H} 2$ is that banks' risk may differentiate the impact of audit quality dimension on banks' income smoothing behavior. We use the dummy variable (RISK) in order to classify banks as high risk and low risk. Our variable takes the value 1 if a bank is classified as high risk and 0 otherwise. We follow Leventis et al. (2011) and we use the Z-SCORE in order to measure banks' risk. The Z-SCORE measures the distance from insolvency (Laeven \& Levine, 2009) and it is computed as follows:

\section{$\mathrm{z}=(\mathrm{ROA}+\mathrm{CAR}) / \boldsymbol{\sigma}(\mathrm{ROA})$}

where:

$\begin{array}{ll}\text { ROA } & \text { Net income of the current year } t / \text { Total assets of the current year } t \\ \text { CAR } & \text { Total capital ratio of the current year } t \\ \text { O(ROA) } & \text { Standard deviation of ROA for the period 2006 -2013 }\end{array}$

We compute the Z- SCORE for each bank of our sample for the period between 2006-2013. If a bank's Z- SCORE is below the median of the sample, the bank is classified as low risk and high risk otherwise.

In order to capture auditors' industry expertise we construct the dummy variable AUDEXP. Prior studies suggest that industry specialization/expertise is typically measured by an auditor's industry market share in each country (Balsam et al., 2003; Krishnan, 2003). Adopting the approach of Kanagaretnam et al. (2010b), we calculate an auditor's market share as the fraction of a bank's total assets to the total assets of all banks in the specific market. The audit firm with the highest fraction for the 
year's 2006 - 2013 will be classified as an industry expert. Our dummy variable will take the value 1 if the auditor is an industry expert and 0 otherwise.

Furthermore, we include the dummy variable AUDTENURE in order to capture the length of auditor-client relationship. The variable takes the value 1 when a bank retains the same auditor for a consecutive year and 0 when the bank switches the auditor. This approach seems to apply better with our risk approach, because the decision for an auditor switch is endogenous and we cannot distinct if the decision is related with the bank or the audit firm.

To investigate whether the extent of audit quality impact differs between high risk and low risk banks we use the interaction terms EBPTt X RISK X AUDEXP and EBPTt X RISK X AUDTENURE. The first interaction term examines whether industry expertise, as an audit quality dimension, differs between high and low risk banks (H1). Similarly, the second interaction term investigates the influence of audit tenure on income smoothing with regard to banks' risk level. If audit quality dimensions reduce income smoothing through LLPs for high risk banks relative to low risk ones, we expect that the level of income smoothing for the former cluster is significantly lower relative to the level of income smoothing for the second cluster.

The third and fourth hypotheses examine the impact of industry expertise and auditor tenure on income smoothing behavior of GSIBs and non-GSIBs. The classification of the banks into the above categories is based on 2014 European Banking Authority (hereinafter, EBA) list which classifies 35 EU banks into the category of GSIBs. To investigate our hypotheses, we include the dummy variable GSIB that takes the value 1 if a bank is classified as a GSIB and 0 otherwise. Within this context, if audit quality dimensions reduce income smoothing through LLPs for G-SIBs banks relative to non-GSIB ones, we expect that the level of income smoothing for the former cluster is significantly lower to the level of income smoothing of the second cluster.

In addition, we control for country - fixed effects similar with previous cross-country studies (Fonseca \& Gonzalez. 2008; Gebhardt \& Farkas, 2011). The control for timeinvariant unobserved heterogeneity at country level is needed in order to offset potential endogeneity problems from omitted variable bias (Hamadi et al., 2016). Furthermore, we control for period effects by including time variables for each period of our analysis. This control aims to capture any bias resulting from important facts such as the crisis period of 2007-2009.

The following table (Table 2) summarizes our sign predictions for the association of LLPs with the independent variables: 
Table 2. Expectations for the signs of the variables

\begin{tabular}{lc}
\hline Variable & Sign \\
\hline LLPt & $N . A$ \\
NPLt & + \\
$\Delta$ NPLt & + \\
NCOt & - \\
ALWt-1 & + \\
SIZEt-1 & + - \\
$\Delta$ GDPt & - \\
$\Delta$ UNEMPt & + \\
LOANt & + \\
EBPTt & + \\
AUDEXP & + \\
RISK & + \\
EBPTt X RISK X AUDEXP & + \\
AUDTENURE & + - \\
EBPTt X RISK X AUDTENURE & + - \\
GSIB & + \\
EBPTt X GSIB X AUDEXP & $+/-$ \\
EBPTt X GSIB X AUDTENURE & $+/-$ \\
\hline
\end{tabular}

\section{Results}

The results of the descriptive statistics are presented in Tables 3, 4 and 5. In particular, the univariate analysis includes the mean and the standard deviation for the dependent and the independent variables for the pooled sample and the clusters of our analysis as well. Our pooled sample consists of 1064 observations for the period of 2006-2013. Our analysis implies that KPMG comprises the industry expert as it retains an average of $28 \%$ of the total assets of our sample during the period of 20062013. This percentage is depicted by 344 observations and comprises a $32.3 \%$ of our total observations. The banks that selected KPMG as an auditor appear to perform marginally better, since the average earnings before provisions and taxes (EBPTt) is 0.017 and is greater than the respective one of the non-experts group (0.016). Furthermore, KPMG's clients appear more conservative with an average of 0.009 LLPs (LLPt), which is greater than the average of 0,008 for the non-expert cluster. The greater conservatism is also supported by the higher average of loans that have been classified as non-performing (NPAt), which amounts at 0.071 and exceeds the non-expert average of 0.067 . Regarding the auditor tenure, sample banks appear to retain the same auditor for a long period. Our results show that only 
63 times a bank's management decided to change its auditor. An auditor's consecutive engagement may result in higher and more timely error detection, increasing a bank's reliability. Banks with high auditor tenure appear to perform better relative to the banks with an auditor change. The average of earnings before provisions and taxes (EBPTt) is 0.017 for the first group and 0.011 for the second one. In addition, banks that changed their auditor have a greater average of LLPs (LLPt) relative to banks which retain their auditor. This result may imply that new auditors apply more conservative accounting when they substitute their predecessors.

Table 3. Descriptive Statistics

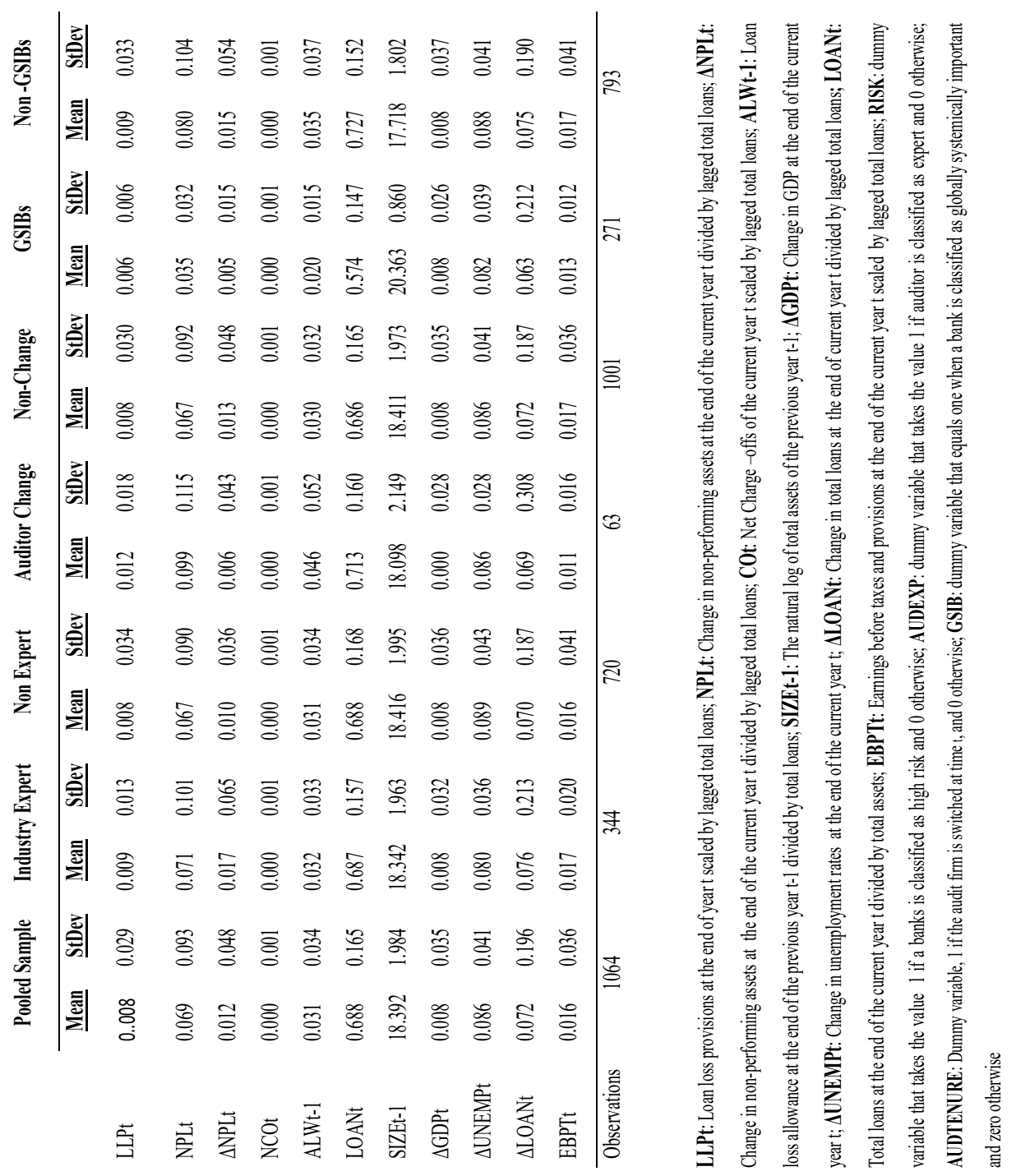


Table 4 presents the mean and the standard deviation of LLPs and earnings before provisions and taxes (EBPt) respectively for our clusters with regard to a bank's idiosyncratic risk. The analysis of the pooled sample implies that although the mean of LLPs for High risk and low risk banks is marginally equal, high risk banks appear more profitable with a mean of earnings before provisions and taxes (EBPt) that amounts at 0,018 and is greater than the respective mean of low risk banks $(0.015)$. These findings imply that riskier banks invest in more profitable projects relative to risk-averse banks. Furthermore, riskier banks appear to engage in industry experts auditors more than lower risk banks. This view is supported by the fact that almost $35 \%$ of high risk banks engage with KPMG. In contrast, this percentage is lower for risk-averse banks $(29 \%)$. With regard to auditor tenure, high risk banks appear to change an auditor 38 times which is slightly higher than the 25 times of low-risk banks.

Table 4. Descriptive Statistics (High Risk vs Low Risk)

\begin{tabular}{|c|c|c|c|c|c|c|c|c|c|c|c|}
\hline \multirow[b]{2}{*}{ 亮 } & & \multicolumn{4}{|c|}{ High Risk } & \multicolumn{4}{|c|}{ Low Risk } & \multicolumn{2}{|c|}{ Pooled Sample } \\
\hline & & 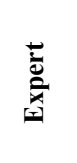 & 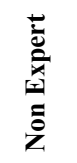 & 总 & 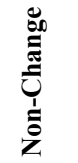 & 这 & 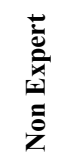 & 总 & 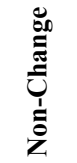 & 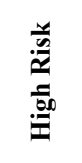 & $\begin{array}{l}y \\
0 \\
0 \\
0 \\
0 \\
0\end{array}$ \\
\hline \multirow[t]{2}{*}{ LLPs } & Mean & 0.008 & 0.008 & 0.015 & 0.008 & 0.011 & 0.008 & 0.008 & 0.008 & 0.008 & 0.008 \\
\hline & StDev & 0.013 & 0.049 & 0.022 & 0.041 & 0.012 & 0.010 & 0.006 & 0.011 & 0.040 & 0.011 \\
\hline \multirow[t]{3}{*}{ EBPt } & Mean & 0.018 & 0.018 & 0.014 & 0.018 & 0.016 & 0.014 & 0.006 & 0.015 & 0.018 & 0.015 \\
\hline & StDev & 0.020 & 0.057 & 0.016 & 0.033 & 0.018 & 0.049 & 0.014 & 0.018 & 0.033 & 0.018 \\
\hline & Obs & 187 & 341 & 38 & 490 & 157 & 379 & 25 & 511 & 528 & 536 \\
\hline
\end{tabular}

Table 5 provides analysis for the clusters of GSIBs and non-GSI banks. The analysis of the pooled samples shows that GSIBs recognize lower LLPs than the rest of banks because the mean of LLPs is 0.006 and 0.009 respectively. Despite the difference in provisioning behavior, GSIBs appear less profitable with a mean of earnings before provisions and taxes (EBPt) that amounts at 0.013 and the respective mean for the rest of banks is 0.017 . Regarding industry expertise, GSIBs appear to engage with industry experts less than the rest of banks since the number of 187 observations represents the $30 \%$ of the 271 observations for GSIBs. On the other hand, this percentage amounts at $33 \%$ for the rest of banks (263 observations from the total of 793). Furthermore, GSIBs changed their auditor 16 times while the rest of banks did for 47 times during the investigated period.

Table 5. Descriptive Statistics (GSIBs vs Non-GSIBs)

\begin{tabular}{|c|c|c|c|c|c|c|c|c|c|c|c|}
\hline & & \multicolumn{4}{|c|}{ GSIB } & \multicolumn{4}{|c|}{ Non-GSIBs } & \multicolumn{2}{|c|}{ Pooled Sample } \\
\hline ariable & & Expert & $\begin{array}{c}\text { Non } \\
\text { Expert }\end{array}$ & $\begin{array}{l}\text { Auditor } \\
\text { Change }\end{array}$ & $\begin{array}{c}\text { Non- } \\
\text { Change }\end{array}$ & Expert & $\begin{array}{c}\text { Non } \\
\text { Expert }\end{array}$ & $\begin{array}{c}\text { Auditor } \\
\text { Change }\end{array}$ & $\begin{array}{c}\text { Non- } \\
\text { Change }\end{array}$ & GSIB & Non- \\
\hline \multirow[t]{2}{*}{ LLPs } & Mean & 0.005 & 0.006 & 0.006 & 0.006 & 0.011 & 0.009 & 0.015 & 0.009 & $\overline{0.006}$ & 0.009 \\
\hline & StDev & 0.005 & 0.006 & 0.005 & 0.006 & 0.014 & 0.040 & 0.020 & 0.034 & 0.006 & 0.033 \\
\hline \multirow[t]{3}{*}{ EBPt } & Mean & 0.015 & 0.012 & 0.003 & 0.014 & 0.018 & 0.017 & 0.013 & 0.018 & 0.013 & 0.017 \\
\hline & StDev & 0.017 & 0.012 & 0.011 & 0.012 & 0.039 & 0.047 & 0.017 & 0.042 & 0.012 & 0.041 \\
\hline & $\overline{\text { Obs }}$ & 81 & 190 & 16 & 255 & 263 & 530 & 47 & 746 & 271 & 793 \\
\hline
\end{tabular}


The results of ordinary correlation analysis are presented in Table 6 . In line with our predictions, LLPs (LLPt) are positively related with non-performing loans (NPLt) and their annual change ( $\triangle \mathrm{NPLt}$ ), as well. This evidence implies that banks recognize greater LLPs when the amount of non-performing loans increases (Hamadi et al., 2016). Similarly, LLPs are positively related with the total amount of loans (LO$\mathrm{ANt}$ ), a fact that is in line with previous arguments which imply that banks recognize higher provisions when they have a large portfolio of loans due to higher credit risk. Furthermore, LLPs (LLPt) are negatively related with net charge-offs (COt) and this evidence supports the argument that banks reverse their LLPs, when actual loan losses occur (Nichols et al., 2009). In addition, our independent variable is positively associated with loan loss allowance of the previous year, which supports our predictions that past LLPs policy influences current year's provisions (Beatty \& Liao, 2014). With regard to macroeconomic factors, independent variable (LLPt) is negatively associated with GDP annual growth $(\triangle \mathrm{GDPt})$ and banks' loan growth $(\triangle \mathrm{LOANt})$. These results imply that banks recognize lower LLPs during economic booms. These findings are in line with our predictions and the arguments of previous literature (Laeven \& Majnoni, 2003). Regarding, management's accounting discretion, the correlation analysis shows that LLPs are positively associated with earnings before provisions and taxes (EBPTt) and this evidence confirms the income smoothing hypothesis, which assumes that when income is high, managers recognize higher provisions to use them for a 'rainy day' (Greenawalt \& Sinkey, 1989).

Table 6. Correlation matrix

\begin{tabular}{|c|c|c|c|c|c|c|c|c|c|c|c|c|c|c|c|}
\hline & LLPtt & NPLt & ANPLt & $\mathrm{cot}$ & ALWt-1 & LOAN & SIZEt-1 & $A G D P t$ & ALOANt & SUNEMPS & EBPTt & RISK & AUDEXP & $\begin{array}{l}\text { AUDTE } \\
\text { NURE }\end{array}$ & GSIB \\
\hline LLPRt & 1.000 & & & & & & & & & & & & & & \\
\hline NPLd & 0.270 & 1.000 & & & & & & & & & & & & & \\
\hline$\Delta N P L d t$ & 0.121 & 0.435 & 1.000 & & & & & & & & & & & & \\
\hline $\mathrm{cot}$ & -0.030 & -0.028 & -0.041 & 1.000 & & & & & & & & & & & \\
\hline ALWt-1 & 0.324 & 0.680 & 0.144 & -0.011 & 1.000 & & & & & & & & & & \\
\hline LOAN & 0.089 & 0.245 & 0.138 & 0.053 & 0.227 & 1.000 & & & & & & & & & \\
\hline SIZEt-1 & -0.044 & -0.175 & -0.056 & -0.045 & -0.221 & -0.360 & 1.000 & & & & & & & & \\
\hline$\triangle G D P t$ & -0.158 & -0.181 & -0.121 & -0.106 & -0.213 & -0.065 & 0.001 & 1.000 & & & & & & & \\
\hline AldoNAt & -0.031 & -0.056 & 0.155 & -0.040 & -0.210 & 0.052 & -0.049 & 0.280 & 1.000 & & & & & & \\
\hline AUNEMVAR & 0.175 & 0.272 & 0.166 & 0.081 & 0.384 & 0.117 & -0.069 & -0.271 & -0.143 & 1.000 & & & & & \\
\hline ERPTt & 0.663 & 0.031 & 0.054 & -0.102 & -0.019 & -0.076 & -0.075 & 0.169 & 0.266 & -0.006 & 1.000 & & & & \\
\hline RISK & -0.001 & 0.106 & 0.027 & 0.044 & 0.124 & 0.132 & -0.157 & 0.073 & 0.008 & -0.111 & 0.045 & 1.000 & & & \\
\hline AUDEXP & 0.023 & 0.021 & 0.062 & 0.000 & 0.007 & -0.005 & -0.017 & -0.008 & 0.013 & -0.102 & 0.019 & 0.065 & 1.000 & & \\
\hline AUDTEN- & -0.035 & -0.080 & 0.035 & -0.011 & -0.105 & -0.037 & 0.037 & 0.057 & 0.003 & -0.000 & 0.038 & 0.053 & -0.005 & 1.000 & \\
\hline GSIB & -0.053 & -0.210 & -0.086 & -0.249 & -0.204 & -0.404 & 0.581 & 0.004 & -0.026 & -0.064 & -0.053 & -0.135 & -0.030 & 0.000 & 1.000 \\
\hline
\end{tabular}

*Bold coefficients are statistically significant

LLPt: Loan loss provisions at the end of year t scaled by lagged total loans; NPLt: Change in non-performing assets at the end of the current year $t$ divided by lagged total loans; $\triangle \mathbf{N P L t}$ : Change in non-performing assets at the end of the current year $t$ divided by lagged total loans; COt: Net Charge -offs of the current year t scaled by lagged total loans; ALWt-1: Loan loss allowance at the end of the previous year t-1 divided by total loans; SIZEt-1: The natural log of total assets of the previous year t-1; $\mathbf{G D P t}$ : Change in GDP at the end of the current year t; $\Delta$ UNEMPt: Change in unemployment rates at the end of the current year t; $\triangle$ LOANt: Change in total loans at the end of current year t divided by lagged total loans; LOANt: Total loans at the end of the current year t divided by total assets; EBPTt: Earnings before taxes and provisions at the end of the current year $t$ scaled by lagged total loans; RISK: dummy variable that takes the value 1 if a banks is classified as high risk and 0 
otherwise; AUDEXP: dummy variable that takes the value 1 if auditor is classified as expert and 0 otherwise; AUDTENURE: Dummy variable, 1 if the audit firm is switched at time t, and 0 otherwise; GSIB: dummy variable that equals one when a bank is classified as globally systemically important and zero otherwise

The results of the multivariate analysis for the first hypothesis $(\mathrm{H} 1)$ are presented in Table 7. Our first hypothesis (H1) investigates whether the impact of auditor industry expertise on banks' income smoothing incentives depends on the level of each individual bank's risk. Similarly, to previous studies, our results imply a positive association of LLPs (LLPt) with the current year's change of non-performing loans ( $\triangle$ NPLt) (Gebhatrdt \& Farkas, 2011; Hamadi et al., 2016) and a positive association with current year's net charge-offs (COt) (Nichols et al., 2009). However, these relations are not significant. Our findings show that there is a positive and significant association between LLPs (LLPt) and the loan loss allowance at the beginning of the year (ALWt-1). This finding is in line with the results of the correlation analysis and the arguments of Beatty and Liao (2014) who suggested that previous year's accounting decisions may influence current LLPs' recognition. Furthermore, our results support the arguments that general macroeconomic conditions influence banks' managers' accounting decisions. In particular, LLPs (LLPt) are negatively associated with GDP growth $(\triangle \mathrm{GDPt})$ and loan growth $(\triangle \mathrm{LOANt})$. This finding is in line with Beatty and Liao (2011) who suggested that LLPs tend to be higher during economic recessions, when financial development is low and borrowers' credit risk is high. The positive and significant association between LLPs (LLPt) and size (SIZEt-1) may be explained by the political cost hypothesis which predicts that larger firms aim to decrease income and avoid a potential political intervention in their business (Watts \& Zimmerman, 1986). Regarding the income smoothing hypothesis, our results suggest that there is a positive and significant association between LLPs (LLPt) and earnings before provisions and taxes (EBPTt), which implies that managers smooth income through LLPs (Greenawalt \& Sinkey, 1989; Hamadi et al., 2016). The triple interaction term EBPTt X RISK X AUDEXP reflects the impact of auditor's industry expertise on income smoothing. The results of the multivariate analysis show that there is a negative and significant association between the interaction term and LLPs. This finding implies that when a bank's audit is performed by an industry expert, high risk banks appear to smooth income less than low-risk ones. From an economic perspective, auditors who are industry experts may be more competent in detecting fraud and misstatements than auditors who are not industry -experts (Carcello \& Nagy, 2004; Reichelt \& Wang, 2010). Consequently, their advantage may improve accounting quality by mitigating managers' accounting discretion of high risk banks which engage more in excessive risk-taking and income smoothing practices through discretionary LLPs Leventis et al. (2011). 
Table 7. Impact of risk on the association between auditor industry specialization

\begin{tabular}{lccc}
\hline & Sign & Coefficient & t-stat \\
\hline CONSTANT & & $-0.033^{* *}$ & -2.141 \\
NPLt & - & -0.010 & -0.683 \\
$\Delta \mathrm{NPLt}$ & + & 0.013 & 0.799 \\
COt & + & 0.383 & 0.510 \\
ALWt-1 & + & $0.314^{* * *}$ & 7.087 \\
LOANt & + & $0.016^{* * *}$ & 2.748 \\
SIZEt-1 & + & $0.000^{*}$ & 1.832 \\
$\Delta$ GDPt & - & $-0.244^{* * *}$ & -4.488 \\
$\Delta$ LOANt & - & $-0.014^{* *}$ & -2.003 \\
UUNEMPt & + & $0.050^{*}$ & 1.708 \\
EBPTt & + & $0.703^{* * *}$ & 3.229 \\
RISK & + & 0.001 & 1.477 \\
AUDEXPERT & + & $0.002^{* *}$ & 2.007 \\
EBPTt x RISK x AUDEXPERT & - & $-0.282^{* *}$ & -1.965 \\
\hline Country Fixed effects & Yes & & \\
Year Dummies & Yes & & \\
\hline R-Squared & 0.70 & & \\
Observations & 1064 & & \\
\hline
\end{tabular}

Our second hypothesis (H2) investigates whether the impact of auditor tenure on banks' income smoothing incentives depends on the level of each individual bank's risk. The results of the regression analysis are presented in Table 8. LLPs are positively associated with annual change non-performing loans ( $\triangle \mathrm{NPLt})$. However, this association is not significant. In addition, LLPs (LLPt) are positively but no-significantly related with net charge-offs $(\mathrm{COt})$ and positively associated the loan loss allowance at the beginning of the year (ALWt-1). Furthermore, in line with the correlation analysis' results, LLPs are significantly influenced by macroeconomic factors, since there is a negative association with annual growth of GDP ( $\triangle \mathrm{GDPt})$ and loans ( $\triangle$ LOANt). In line with our predictions, LLPs are positively and significantly associated with earnings before provisions and taxes (EBPTt), a finding that suggest that banks engage in income smoothing through LLPs (Gebhardt and Farkas, 2011). The triple interaction term EBPTt X RISK X AUDTENURE reflects the impact of auditor's tenure on income smoothing. Our regression results show that LLPs are significantly associated with our interaction term and this relation is positive. This finding implies that when banks retain their auditor, high-risk banks appear to smooth income more than low-risk ones. As a result auditor tenure appears to be a critical factor for improving accounting quality. In particular, clients that retain their auditors for a consecutive period become more likely to engage in income smoothing. This may explained by the fact that as auditor-client relationship lengthens, auditors may act in favor of management and this fact that reduces audit quality (Carey \& Simnett, 2006; Bamber \& Iyer, 2007; Amahalu, 2019)). The aforementioned perspective appears to be more important regarding banks' idiosyncratic risk because riskier banks are more encouraged to put pressure on their auditors and increase their opportunities earnings 
management and masking excessive risk-taking. This finding is in line with Myers et al. (2003) and Chen et al. (2008) who found that auditor tenure is positively associated with earnings management.

Table 8. Impact of risk on the association between auditor tenure and income smoothing

\begin{tabular}{lccc}
\hline & Sign & Coefficient & t-stat \\
\hline CONSTANT & - & -0.004 & -0.494 \\
NPLt & - & -0.007 & -0.496 \\
$\Delta$ NPLt & + & 0.016 & 1.084 \\
COt & + & 0.644 & 0.837 \\
ALWt-1 & + & $0.306^{* * *}$ & 6.807 \\
LOANt & + & $0.012^{* * *}$ & 2.816 \\
SIZEt-1 & + & 0.000 & 0.765 \\
$\Delta$ GDPt & - & $-0.211^{* * *}$ & -4.485 \\
$\Delta$ LOANt & - & $-0.012^{* *}$ & -2.037 \\
$\Delta$ UNEMPt & + & $0.040^{*}$ & 1.663 \\
EBPTt & + & $0.263^{* * *}$ & 3.569 \\
RISK & - & $-0.006^{* * *}$ & -2.819 \\
AUDTENURE & - & $-0.006^{* *}$ & -2.301 \\
EBPTt x RISK x AUDTENURE & + & $0.484^{* * *}$ & 2.869 \\
\hline Country Fixed effects & Yes & & \\
Year Dummies & Yes & & \\
\hline R-Squared & 0.73 & & \\
Observations & 1064 & & \\
\hline
\end{tabular}

Our third and fourth hypotheses (H3 \& H4) examine whether the impact of industry expertise and auditor tenure on income smoothing behavior is different between GSIBs and non GSIBs. The results of multivariate analysis for both panels are presented in Table 9. The interaction term EBPTt X GSIB X AUDEXPERT aims to examine whether the impact of industry expertise differs between GSIBs and non GSIBs. Similarly, the EBPTt X RISK X AUDTENURE investigates potential differences for the association of auditor tenure with banks' income smoothing behavior. Panel A presents the results for the third hypothesis (H3). In line with our predictions, LLPs have a positive and significant association with loan loss allowance of the previous year (ALWt-1), the amount of total lending (LOANt) and earnings before provisions and taxes (EBPTt). On the other hand, our dependent variable has a negative and significant association with GDP growth ( $\triangle \mathrm{GDPt})$ and loan growth ( $\triangle \mathrm{LOANt})$. The negative association of LLPs with the term EBPTt X GSIB X AUDEXPERT implies that industry specialization decreases accounting discretion and this impact is higher for GSIBs. Given that GSIBs are more complex organizations, the limitation of accounting discretion is more challenging for banks' monitors. Within this context, auditors that appear as industry experts may be more efficient in detecting accounting fraud and errors. Consequently, our results imply that GSIBs which are audited by 
industry experts are less likely to engage in discretionary accounting choices. Furthermore, these results may imply that the presence of an auditor expert will increase accounting conservatism regarding LLPs recognition in order to decrease high earnings for fear of political and/or regulatory scrutiny of bank earnings (Nelson et al., 2002). Panel B presents the multivariate results for the impact of auditor tenure. Similarly, with Panel A, the term EBPTt X GSIB X AUDTENURE is negatively related with LLPs and this association is significant. Similarly with Panel A, our findings imply that auditor tenure mitigates income smoothing and this impact is higher for GSIBs. This association may be explained by the fact that as auditor client relationship lengthens, auditors gain advantage by understanding the business model and accounting practices of their client and this fact improves audit and accounting quality. This evidence is in line with the results of Gaver and Paterson (2007) and Kanageretnam et al. (2010a) that showed that auditors tolerate less earnings management in larger clients of the financial sector. This evidence complements the results of Peterson and Arun (2018) who found that GSIBs exhibit greater income smoothing than the rest of banks under certain circumstances.

Table 9. Impact of auditor industry specialization and auditor tenure on Income Smoothing between GSI banks and rest of banks

\begin{tabular}{|c|c|c|c|c|c|c|}
\hline & \multicolumn{3}{|c|}{ Industry Specialization } & \multicolumn{3}{|c|}{ Auditor Tenure } \\
\hline & Sign & $\begin{array}{c}\text { Coeffi- } \\
\text { cient }\end{array}$ & t-stat & Sign & $\begin{array}{c}\text { Coeffi- } \\
\text { cient }\end{array}$ & t-stat \\
\hline$\overline{\text { CONSTANT }}$ & - & -0.032 & -2.005 & - & -0.029 & -1.931 \\
\hline NPLt & - & -0.007 & -0.505 & - & -0.006 & -0.462 \\
\hline$\triangle \mathrm{NPLt}$ & + & 0.011 & 0.672 & + & 0.013 & 0.813 \\
\hline $\mathrm{COt}$ & + & 0.528 & 0.680 & + & 0.405 & 0.548 \\
\hline ALWt-1 & + & $0.296 * * *$ & 6.570 & + & $0.295 * * *$ & 6.488 \\
\hline LOANt & + & $0.015^{*}$ & 2.728 & + & $0.014 * * *$ & 2.699 \\
\hline SIZEt-1 & + & $0.000 *$ & 1.676 & + & $0.001 * *$ & 1.727 \\
\hline$\Delta \mathrm{GDPt}$ & - & $0.250^{*} * *$ & -4.503 & - & $0.258^{-} * *$ & -4.510 \\
\hline$\triangle \mathrm{LOANt}$ & - & $0.015^{* *}$ & -2.049 & - & $0.014 * *$ & -2.021 \\
\hline$\triangle \mathrm{UNEMPt}$ & + & $0.053 *$ & 1.755 & + & $0.048 *$ & 1.668 \\
\hline EBPTt & + & $0.696 * * *$ & 3.198 & + & $0.701 * * *$ & 3.222 \\
\hline GSIB & + & $0.002 *$ & 1.680 & + & $0.003 *$ & 1.790 \\
\hline AUDEXPERT & + & 0.000 & 0.839 & & & \\
\hline EBPTt $x$ GSIB $\times$ AUDEX- & & - & & & & \\
\hline PERT & - & $0.399 *$ & -2.648 & & & \\
\hline AUDTENURE & & & & - & -0.002 & -1.225 \\
\hline EBPTt $x$ GSIB $x$ & & & & & - & \\
\hline AUDTENURE & & & & - & $0.363 * *$ & -2.081 \\
\hline
\end{tabular}




\begin{tabular}{lcclccc}
\hline & \multicolumn{2}{c}{ Industry Specialization } & & \multicolumn{2}{c}{ Auditor Tenure } \\
\cline { 2 - 3 } \cline { 5 - 6 } & Sign $\begin{array}{c}\text { Coeffi- } \\
\text { cient }\end{array}$ & t-stat & & Sign & $\begin{array}{c}\text { Coeffi- } \\
\text { cient }\end{array}$ & t-stat \\
\hline Country Fixed effects & Yes & & Yes & \\
Year Dummies & Yes & 0.73 & & & Yes & \\
\hline R-Squared & 1064 & & & 0.70 & \\
Observations & & & 1064 & \\
\hline
\end{tabular}

\section{Conclusions}

Our study investigates the impact of specific audit quality dimensions upon the EU banks' accounting policy decisions. In particular, our study examines whether auditor industry specialization and auditor tenure limit management's accounting discretion and whether these associations are influenced by the clients' importance and their idiosyncratic risk.

Regarding the clients' idiosyncratic risk, we followed Leventis et al. (2011) and we classified our banks as high risk and low risk banks. Our findings provided evidence auditors' industry expertise limits management's discretion of high risk banks to a greater extent relative to low risk banks. Our results complement the findings of Leventis et al. (2011) argued that high risk banks engage more in income smoothing practices through discretionary LLPs. Furthermore, we are in line with previous arguments which suggest that industry expertise may mitigate managers' accounting discretion (Carcello \& Nagy, 2004; Reichelt \& Wang, 2010). In conclusion, auditors with industry expertise are critical for audit quality because they appear competent enough to limit the increased managerial discretion of riskier banks (Leventis et al., 2011).

In contrast, our results imply that banks that retain the same auditor for a consecutive fiscal year are more likely to engage in income smoothing through LLPs. This finding is in line with Myers et al. (2003) and Chen et al. (2008) who found that auditor tenure is positively associated with earnings management. This result may imply that when high risk banks retain their auditors for several years, accounting discretion may increase as auditors may act in the favor of managers (Bamber \& Iyer, 2007).

Furthermore, our study examines whether audit quality dimensions have different outcomes on income smoothing decisions between GSIBs and non-GSIBs. Our findings imply that audit quality dimensions influence banks' income smoothing behavior and this association differs between GSIBs and the rest of banks. In particular, our results imply that auditors tolerate less earnings management in larger clients of the financial sector. This finding is in line with Manry et al. (2008) who support that auditors tolerate less earnings management in larger clients. Furthermore, our results complement Gul et al. (2009) who found that in when earnings quality is reduced, 
the presence of an industry specialist moderates the negative effect of the association between auditor tenure and earnings management.

This study focused on the interrelationship between certain dimensions of audit quality and banks' accounting policy decisions. The empirical findings contribute in the existing literature by examining further aspect of the association between audit and financial reporting quality. Our results may be useful for regulators and policy makers who aim to protect banks' stakeholders from banks' excessive risk taking and management's opportunistic incentives. Regulators who aim to enhance the EU audit policy should consider banks' risk attributes and their impact on audit quality. Furthermore, our results may be useful for auditors, who want to maintain high levels of independence, because they imply that banks' risk may differentiate the outcomes of certain attributes of independence.

Our study offers certain implications for future research. In particular, future studies should investigate the impact of the Basel framework on audit quality dimensions and the stricter regulatory constraints of GSIB. Furthermore, researchers should also investigate the competition in the audit market and compare results with mandatory auditor rotation.

\section{References}

AICPA (2006) "Large Firm PCAOB Inspection Deficiency Analysis." <http:// www.aicpa.org/cpcaf/download/PCAOB_Inspection_Deficiency_Analysis_January2006.pdf $>$.

Allen, R. D., Hermanson, D. R., Kozloski, T. M. \& Ramsay, R. J. (2006) “Auditor risk assessment: Insights from the academic literature", Accounting Horizons, vol. 20 , no. 2: $157-177$.

Amahalu, N. (2019) "Effect of auditors' rotation on audit quality of quoted deposit money banks in Nigeria", Available at SSRN: https://ssrn.com/abstract $=3704505$.

Anandarajan, A., Hasan, I., \& McCarthy, C. (2007) "Use of loan loss provisions for capital, earnings management and signaling by Australian banks", Accounting \& Finance, vol. 47, no. 3: 357-379.

Autore, D.M., Billingsley, R.S.\& Schneller, M.I. (2009) "Information uncertainty and auditor reputation.", Journal of Banking and Finance, vol. 33, no. 12, 183-192.

Balsam, S., Krishnan, J. \& Yang, J. (2003) "Auditor industry specialization and earnings quality.", Auditing: A Journal of Practice \& Theory, vol. 22, no. 2, 71-97.

Barth, J., G. Caprio, \& R. Levine. (2004) "Bank supervision and regulation: What works best?", available at https://elibrary.worldbank.org/doi/abs/10.1596/ 1813-9450-2725. 
Bamber, E. M., \& Iyer, V. M. (2007) “Auditors'identification with their clients and its effect on auditors' objectivity.", Auditing: A Journal of Practice \& Theory, vol. 26, no. 2, 1-24.

Beatty, A. \& S. Liao. (2011) "Do delays in expected loss recognition affect banks' willingness to lend?", Journal of Accounting \& Economics, vol. 52, no. 1, $1-20$.

Beatty, A.\& S. Liao. (2014) “"Financial Accounting in the Banking Industry: A Review of the Empirical Literature" Journal of Accounting and Economics, vol. 58, no, 2-3: 330-383.

Beaver, W. H. \& Engel, E. E. (1996) "Discretionary behaviour with respect to allowances for loan losses and the behaviour of security prices", Journal of Accounting and Economics, vol. 22, no. 1: 177-206.

Beeler, J. D. \&J. E. Hunton. (2002) "Contingent economic rents: Insidious threats to audit independence.", Advances in Accounting Behavioral Research, vol. 5: 21-50.

Bikker, J.A. \& P.A.J. Metzemakers. (2005) "Bank provisioning behaviour and procyclicality", Journal of International Financial Markets, Institutions and Money, vol. 15, no. 2: 41-157.

Blay, A. D. \& Geiger, M. A. (2013) "Auditor fees and auditor independence: Evidence from going concern reporting decisions", Contemporary Accounting Research, vol. 30, no.2, 579-606.

Caramanis, C. \& C. Lennox. (2011) "Audit effort and earnings management", Journal of Accounting and Economics, vol. 45, no. 1, 116-138.

Carcello, J. \& Nagy, A. (2004) "Client size, auditor specialization and fraudulent financial reporting”, Managerial Auditing Journal, vol. 19, no. 5, 651-668.

Cardelon, T., L. Wang, \& T. Klenoptic. (2012) "Past control risk and current audit fees", Managerial Auditing Journal, vol. 27, no. 2, 693-708.

Carey, P. \& Simnett, R. (2006) "Audit partner tenure and audit quality", The Accounting Review, vol. 81, no. 3, 653-676.

Chang, C. J. \& N.-C. R. Hwang. (2003) "The impact of retention incentives and client business risks on auditors' decisions involving aggressive reporting practices", Auditing: A Journal of Practice \& Theory, vol. 22, no.2, 207-218.

Chen, C., Lin, C., \& Lin, Y. (2008)., "Audit partner tenure, audit firm tenure, and discretionary accruals: Does long auditor tenure impair earnings quality?", Contemporary Accounting Research, vol. 25, no 2, 415-445.

Curcio, D. \& Hasan I., (2013) "Earnings and capital management and signaling: the use of loan-loss provisions by European banks", The European Journal of Finance, vol. 21, no. 1, 26-50.

Davis, L. R., Soo, B. S., \& Trompeter, G. M. (2009) "Auditor tenure and the ability to meet or beat earnings forecasts", Contemporary Accounting Research, vol. 26, no. 2, 517-548.

DeAngelo, L. (1981) “Auditor size and auditor quality.", Journal of Accounting and Economics, vol. 3, no. 3, 183-199. 
Fang, Y., Hasan, I. \& Marton, K. (2014) "Institutional development and bank stability: Evidence from transition countries", Journal of Banking \& Finance, vol. 39, 160-176.

Fonseca, A. R., \& Gonzalez, F. (2008) "Cross-country determinants of bank income smoothing by managing loan-loss provisions", Journal of Banking and Finance, vol. 32, no. 2, 217-228.

Gaver, J. J., \& Paterson, J. S. (2007) "The influence of large clients on office-level auditor oversight: Evidence from the property-casualty insurance industry", Journal of Accounting and Economics, vol. 43, no. (2-3), 299-320.

Gebhardt, G. \& Novotny-Farkas, Z. (2011) "Mandatory IFRS adoption and accounting quality of European banks", Journal of Business Finance \& Accounting, vol.38, no. 3-4, 289-333.

Greenawalt, M. B., \& Sinkey, J. F, (1988) "Bank loan-loss provisions and the income-smoothing hypothesis: An empirical analysis, 1976-1984", Journal of Financial Services Research, vol. 1, no. 4, 301-318.

Gul, F. A., Fung, S. Y., \& Jaggi, B. (2009) "Earnings quality: Some evidence on the role of auditor tenure and auditors' industry expertise", Journal of Accounting \& Economics, vol. 47, no 3, 265-287.

Hamadi, M., Heinen, A., Linder, S., \& Porumb, V. A. (2016) "Does Basel II affect the market valuation of discretionary loan loss provisions?", Journal of Banking \& Finance, vol. 70, 177-92.

Hammersley, J. S., K. Johnstone \& K. Kadous, (2011) "How do audit seniors respond to heightened fraud risk?", Auditing: A Journal of Practice \& Theory, vol. 30 , no. 3, 81-101.

Hackenbrack, K., Jenkins, N. \& Pevzner, M. (2011) "Relevant but delayed information in negotiated audit fees: evidence from stock price crashes", Working paper, Vanderbilt University, University of Kentucky, and George Mason University.

Hribar, P., Kravett, T. D. \& Wilson, R. J. (2010) "A new measure of accounting quality", Working paper, University of Iowa and University of Texas at Dallas.

Johnson, P., Jamal, K. \& Berryman, R. (1991) "Effects of framing on auditor decisions.", Organization Behavior and Human Decision Processes, vol. 50, no. 1, 75-105.

Johnson, V. E., Khurana, I. K. \& Reynolds, J. K. (2002) "Audit-firm tenure and the quality of financial reports.", Contemporary Accounting Research, vol. 19, no. 4, 637-660.

Johnstone, K. \& J. Bedard, (2001) "Engagement planning, bid pricing, and client response to initial attest engagements", The Accounting Review, no. 76, vol. 2, 199-220.

Kanagaretnam, K., Lobo, G. J. \& Yang, D. H., (2005) "Determinants of signaling by banks through loan loss provisions", Journal of Business Research, vol. 58, no. 3, 312-320. 
Kanagaretnam, K., Krishnan, G., Lobo, G.J., (2009) "Is the market valuation of banks' loan loss provision conditional on auditor reputation?", Journal of Banking and Finance, vol. 33, no. 6, 1039-1047.

Kanagaretnam, K., Krishnan, G. V. \& Lobo, G. J. (2010) "An empirical analysis of auditor independence in the banking industry", The Accounting Review, vol. 85, no. 6, 2011-2046.

Kanagaretnam, K., Lim, C. Y., \& Lobo, G. J. (2010b) “Auditor, reputation and earnings management: International evidence from the banking industry", Journal of Banking and Finance, vol. 34, no. 10, 2318-2327.

Knapp, M. C., (1991) "Factors that audit committee members use as surrogates for audit quality", Auditing: A Journal of Practice \& Theory, vol. 10, no. 1, $35-52$.

Krishnan, J., \& Krishnan, J. (1996) "The role of economic trade-offs in the audit opinion decision: An empirical analysis", Journal of Accounting, Auditing \& Finance, vol.11, no.4, 565-586.

Krishnan, G., (2003) "Audit quality and the pricing of discretionary accruals", $A u$ diting: A Journal of Practice \& Theory, vol. 22, no.1, 109-126.

Laeven, L. \& Giovanni, M. (2003) "Loan loss provisioning and economic slowdowns: too much, too late?", Journal of Financial Intermediation, vol. 12 , no.2, 178-197.

Laeven, L., \& Levine, R. (2009) "Bank governance, regulation and risk taking", Journal of Financial Economics, vol. 93, no. 2, 259-275.

Leventis, S., Dimitropoulos, P. E., \& Anandarajan, A. (2011) "Loan loss provisions, earnings management and capital management under IFRS: The case of EU commercial banks", Journal of Financial Services Research, vol. 40, no. (1-2), 103-122.

Levine, Ross. (2003) "The corporate governance of banks", Global Corporate Governance Forum, available at SSRN: https://ssrn.com/abstract=795548

Li, C. (2009) 'Does client importance affect auditor independence at the office level? Empirical evidence from going-concern opinions.', Contemporary Accounting Research, vol. 26, no.1, 201-230.

Lin, J. \& M. Hwang, (2010) "Audit quality, corporate governance, and earnings management: a meta-analysis", International Journal of Auditing, vol. 14, no. 1, 57-77.

Manry, D., Mock, T., \& Turner, J., (2008) "Does increased partner tenure reduce audit quality?", Journal of Accounting, Auditing \& Finance, vol. 23, no. 4, 553-572.

Myers, J., L. Myers \& T. Omer. (2003) "Exploring the term of the auditor-client relationship and quality of earnings: A case for mandatory auditor rotation?", The Accounting Review, vol 78, no. 3, 779-799.

Nelson, M. W., Elliott, J. A., \& Tarpley, R. L. (2002) "Evidence from auditors about managers' and auditors' earnings management decisions", The Accounting Review, vol. 77, no. 1, 175-202. 
Nichols, D., Wahlen, J. \& Wieland, M. (2009) "Publicly-traded versus privatelyheld: implications for conditional conservatism in bank accounting", Review of Accounting Studies, vol. 14, no. 1, 88-122.

Nicoletti, A. (2018) "The effects of bank regulators and external auditors on loan loss provisions", Journal of Accounting and Economics, vol. 66, no. 1, 244-265.

Olszak M, Pipien M., Kowalsa I. \& Roszkowska S. (2017) "What drives heterogeneity of cyclicality of loan-loss provisions in the EU?", Journal of Financial Services Research, vol. 51, 55-96.

Ozili, P. K. (2017a) "Bank earnings smoothing, audit quality and procyclicality in Africa. The case of loan loss provisions', Review of Accounting and Finance, vol.16, no. 2, 142-161.

Ozili, P. K. (2017b) "Discretionary provisioning practices among Western European banks", Journal of Financial Economic Policy, vol. 9, no 1, 109-118.

Ozili, P. K. (2019) "Bank income smoothing, institutions and corruption", Research in International Business and Finance, vol. 49, 82-99.

Peterson, O., \& Arun, T. (2018) "Income smoothing among European systemic and non-systemic banks.", The British Accounting Review, available at https://doi.org/10.1016/j.bar.2018.03.001

Reichelt, K., \& Wang, D. (2010) "National and office-specific measures of auditor industry expertise and effects on audit quality.", Journal of Accounting Research, vol. 48, no. 3, 647-686.

Salem, R., Usman, M. \& Ezeani, E. (2021) "Loan loss provisions and audit quality: Evidence from MENA Islamic and conventional banks", The Quarterly Review of Economics and Finance, vol. 79, 345-359.

Shaub, M. K., \& Lawrence, J. E. (1996) "Ethics, experience and professional skepticism: A situational analysis.", Available at: https://papers.ssrn.com/sol3/papers.cfm?abstract id $=617062$

Sharma, V. D., Sharma, D. S., \& Ananthanarayanan, U. (2011) "Client importance and earnings management: The moderating role of audit committees.", Auditing: A Journal of Practice \& Theory, vol 30, no.3, 125-156.

Shrieves, R, \& Dahl, D., (2003) "Discretionary accounting and the behavior of Japanese banks under financial duress.", Journal of Banking and Finance, vol. 27, no.7, 1219-1243.

Tepalagul, N. \& Ling, L. (2015) "Auditor independence and audit quality: a literature review", Journal of Accounting, Auditing \& Finance, vol. 30, no. 1, 101-121.

Tessema, A. (2020) "Audit quality, political connections and information asymmetry: evidence from banks in gulf co-operation council countries", International Journal of Managerial Finance, vol. 16 no. 5, 673-698

Tran, D. V., Hassan, M. K., \& Houston, R. (2019) "Discretionary loan loss provision behavior in the US banking industry", Review of Quantitative Finance and Accounting, 1-41. 
Ugwu, C. C., Aikpitanyi, L. N. \& Idemudia, S. (2020) "The effect of audit quality on financial performance of deposit money banks - Evidence from Nigeria", Available at SSRN: https://ssrn.com/abstract=3539056.

Vasilakopoulos, K., Tzovas, C. \& Ballas, A. (2018) "The impact of corporate governance mechanisms on EU banks' income smoothing behavior", Corporate Governance, vol. 18 no. 5, 931-953.

Watts, R. \& J. Zimmerman, (1981) “The markets for independence and independent auditors", Unpublished manuscript (University of Rochester, Rochester, NY).

Wilks, T. J. \& Zimbelman, M. F. (2004) "Decomposition of fraud-risk assessments and auditors' sensitivity to fraud cues", Contemporary Accounting Research, vol. 21, no. 3, pp. 719-745.

Yasuda, Y, Okuda, S \& Konishi, M. (2004) "The relationship between bank risk and earnings management: Evidence from Japan", Review of Quantitative Finance and Accounting, vol. 22, no. 3, 233-248.

Zimmerman, J. L. (1983) "Taxes and firm size", Journal of Accounting and Economics, vol. 5, 119-149.

Watts, R. L., \& Zimmerman, J.L. (1986) Positive accounting theory, Pentice Hall, New York 